\title{
Social Capital In Indonesia: Process To Design
}

\author{
Rahel Widiawati Kimbal
}

\begin{abstract}
This research aimed at finding a new design of social capital in order to reinforce sustainable small industrial enterprises. It was conducted on farmers and roasted peanut entrepreneurs as the small business agents. This research used qualitative research method with triangulation technique such as observation, interview, and documentation. To analyze the data, it used Advanced Analytical Method by Spradley.

This research discoverd that the emergence of problems in the small business activities or roasted peanut industry as from the upstream to the downstream. It was severely supported by the negative social capital emerged from these industrial activities. The power of social capital which sometimes fell off actually never stagnated; however, it revived, and it could turn to be positive social capitals in terms of: (1) The Power of Colleague Network, (2) Mutual Trust and Cooperation, (3) Obedience to Life Norms, (4) Mutual Vurtue and, (5) Impact Values of Life. The process of a long journey of social capital has made it even more complete with the formation of a design of social capital through a community/group formed specifically consisting of peanut farmers and roasted peanut entrepreneurs. The set that is intended for: (1) Excavating and Exploring the Resources of Members of the "Association". (2) Protecting and Guarding the Members from Business Threats. (3) Utilizing Every Business Opportunity for Business Development in a Better Version. (4) Identifying and Anticipating every Threat of a Small Business. The process of social capital has become a force contained in the design of social capital which has an overall impact on the strengthening and development of small industrial economies. It also requires support and the role of the government as a regulator for the sustainability of small industrial businesses to continue to take part and be able to prosper the community's economy.
\end{abstract}

Index Terms: Social Capital, Design, Process, Small Industrial Enterprises

\section{INTRODUCTION}

Indonesia a country with the prominent multi cultures has developed and growth since some years ago. Culture that is alive in society certainly puts some power to develop and grow their economic welfare. This culture stand still due to social capital as an energy of Indonesian economic loose strong society foundation but also may run into stagnations and difficulties to discharge from a crisis. As an energy, it will be effective to boost triumph for good policies by both government and private $\left.{ }_{i}\right]$ Indonesian citizens could not separate from social capital since it was built between society which is from high to lower level. It could be a strong bonding in several aspects especially in economic aspect that can be an indicator for public welfare. It was also seen in a small business industry of roasted peanuts. The mutual relationship between peanut farmer and roasted peanut seller is insperable since both of them need each other, grow and develop together in the midst of the social life in North

Revised Manuscript Received on April 19, 2019.

Rahel Widiawati Kimbal, Doctor, Economics Faculty, Universitas Negeri Manado, Tondano, Indonesia.
Sulawesi; therefore, they should not be separable from social capital which influences on this business[ii]. Colemen defines social capital based on its function which consists of compund entity including two elements: first, social capital which includes aspects from social structures, and second, social capital which facilitates certain actions from the actors both individuals and companies within structures[iii]. Therefore, its existence requires to be strengthen with supports of all parties in order to sustain community business which is almost replaced by modern industry. Hopefully, it may build harmonious and prosperous society. The process of social capital is not easy since it involves many parties.

A sociologist, Maclver, explains that social process is a pattern of action whose social relations between group members result a unique characteristic. It may include the conditional changes such as up and down, developed and regressed, disintegrated or integrated. Ginsbers himself defines social process as ways of interaction between individuals and groups including to build cooperations, conflicts, diferentiations, integrations, developments, and loss of social relationship. Furthermore, according to Gillin, social process is in order to describe ways of interaction which can be analyzed when individuals and groups meet and create a system of relationship or whatever happened when some changes disrupt the previous pattern of life [iv]. Process is not an easy thing on how society experience a change when they join a relationship with others. As stated by experts, society is often expected to experience a process of social change to a better way. Before someone knows his group, he is initilly really closed, and he does not want to socialize. However, when an individual belongs to a social group, he/she wants to achive some positive things. They contain main elements in social capital $\left.{ }_{\mathrm{v}}\right]_{\mathrm{v}}$ such as participating in a network, resiprocity, trust, social norms, values, and proactive actions. This research discovers how process of social capital can develope a design for a small business of roasted peanut industry. It is intended to find a design of ideal social capital for the development of sustainable farming business and small industrial business. It can be achieved by optimalizing social capital in community empowerment since it is related to the economic prosperity of the community which begins to be eroded by modern industry.

The special purpose of this research is to discover a theory and a new design in order to construct a theory of social capital in economic institution as the character of qualitative research constructing a finding of empirical research result which may result a substantif theory. 
Therefore, it is expected to contribute in an attempt to understand the economic activities of farming and small industrial business. As well as providing an alternative development of small-scale business enterprises from the threat of big enterprises which increasingly develop, the role and benefit are as the veins driving the economy of community, especially in the area of Kawangkoan District and North Sulawesi province in general, and as a source of local revenue, they can continue to be maintained and preserved.

\section{LITERATURE REVIEW}

This research finds out a process behind the power of social capital. Economic actors fail because of problems of disharmonious relationship surrounding community. Therefore, the success of peanut farmers and roasted peanut sellers is not only determined by financial capital and economic capital. However, what is equally important is the social capital as a set of informal values or norms spreading around group members which possibly join cooperation between them. $\left.{ }_{\mathrm{rvi}}\right]$ There are four elements explained by Lin about social capital such as (1) information flow. In an imperfect market, social ties in strategic location/ hierarchical positions can provide individuals with useful information about opportunities and choices. In the other hand, individuals who do not have strategic position have possibly no profit. With information, individuals may decrease the cost of transaction for carrying out economic activities. Second, social ties may influence the agents such as a supervisor of organization who have crucial role in making decision (such as payroll or promotion). Third, social ties may be given by an organization or an agent as individual's social credentials i.e. something that reflects individual accessibility of resources through network and relation. Fourth, social relationship is expected to reinforce identity and recognation. Reinforcements are essential for mental health maintainance and entitlement to resources.

According to Gillin [vii], there are two social processes as an effect of social interaction namely associative and dissociative pprocess. Associative process essentially has a tendency to make people unite and increase solidarity among group members; therefore, it may form cooperation, accomodation, assimilation, and acculturation. In this process, the most important thing is cooperation as a form of main social interaction. It is carried out by humans in the community in order to achieve interest. Second, accomodation as a form of social process involves two or more individuals or groups trying to adapt to each other and not to interfere each other by preventing, decreasing or stopping such existing tensions that achives stability and balance. Third, assimilation as a process characterized by efforts to reduce differences that exist between individuals or groups of individuals. The fourth is acculturation as a condition when foreign cultures are slowly received and acculturated in the culture itself without causing a loss of its culture. In acculturation, we recognize cultural elements which are easily accepted and tightly accepted. However, disossiative process is as a process which tends to bring members of the community towards division and claim solidarity among its members. We understand three forms of dissociative processes, namely competition, controversy, and conflict.
This research is basically a series of follow-ups from several previous studies conducted by the author. The idea of tracing the application of social capital and developing it in the economic activities of the community associated with small industrial enterprises. This is inseparable from the findings obtained in research related to the role of social capital in the economic transactions of the main community in Pasar Blante, Kawangkoan. In the research entitled "'Social Capital Contribution to Economic Actors in Mix barter Transaction In Pasar Blante, it explains that social capital institutionally has a vital role in the economic activities of the people who generally live as farmers in Kawangkoan [viii]. Social capital is discovered to encourage some economic transactions while increasing the income of economic actors in the Blante market. This finding is reaffirmed by the continuation of the second year research (2015) which shows that a design of social capital is required for the development of economic activities that occur in Blante Market as one of the transaction center of rural agrarian communities in Kawangkoan area [ix]. Furthermore, the research on the revitalization of social capital has resulted in the findings of various problems in small industrial enterprises in the form of: (1) Capital Limitations, (2) Seasonal Production, (3) Traditional Processing, (4) Simple Outputs, (5) Low Production Quality Control, (6) Weak Management, (7) Low Bargaining Power of Products, (8) Less Market Information, (9) Strict Competition, (10) Lack of Innovation, (11) Unauthorized Patent Rights. Therefore, It is identified that there is negative social capital which created by destructive behavior of a few people who seek a momentary advantage in terms of : (1) selling non-quality raw materials, (2) closed sales and price information, (3) capital loan distrust, (4) the secret of a business science, (5) agreement in dishonesty $[\mathrm{x}]$.

\section{METHODOLOGY}

This research uses qualitative research method. The specific contexts investiaged are social phenomena related to the behavior and social interaction of farmers and traders of roasted peanuts in the community.

As described in the research aims, it focuses to discover the design of social capiral to develop sustainable farm business and small industrial business. The data were taken from informants who have relationship with some activities of small idustrial business, events found in the field, and documents related to the data. $\left[{ }_{x i}\right]$ The data were colledcted in qualitative research conducted from the saturated level of early information, which meant that they possessed chosen data and developed to the candidate of following informant They were chosen by snowball method, and they took turn which finally reached to the last information which achieved saturated level. It meant no other variation of answer from informant.

The research location was placed in Kawangkoan, and it focused on entrepreneurs of roasted peanut small industrial enterprises. Data were taken and analyzed with the gradual advance model by Spradley [xii] which consisted of domain 
analysis, taxonomy, and componential. In domain prespective, the researcher explains that elements and roles of social capital through data which had collected and involved categories such as cover term, beahviorism, and semantic relationship.

The process of analysis is then carried out taxonomically especially to explain the terms or parts of behavior in a special domain and in order to organize in order to achieve the research objectives. In this case the researcher chooses one domain that has semantic similarity to be used later for the chosen domain. In this process the researcher will also look for part terms through constructing structural questions. The final analysis using theme analysis or discovering cultural themes, is actually an attempt to find a common thread that integrates existing domains [xiii].

\section{RESULT AND DISCUSSION}

The long process of of social capital journey to form a design is not easy because the process must pass various forms of social capital created in the community. Both negative and positive social capital are inseparable from the various existed weaknesses. Negative social capital itself is created through the destructive behavior of a few people who seek profit. This can be identified in: (1) selling nonquality raw materials, (2) information on closed sales and prices, (3) distrust of capital loans, (4) secrets of a business science and, (5) dishonesty on an agreement. The form of negative social capital is an obstacle to the development of small industrial businesses to continue to survive in the business world. But the emergence of positive social capital is a savior. This small industrial business of roasted beans can rise again and be found in several ways.

4.1 The Forms of Positive Social Capitals on Small Industrial Enterprises of Roasted Peanut

\subsubsection{The Power of Colleague Network}

The relationship between farmers and entrepreners of rasted peanut has been intertwined through the long process. It is revealed through a statement of Mr. Frely, a peanut farmer.

"I have cultivated peanuts for 30 years. At the beginning, this business was just a fad; however, it look prospective. Therefore, I continue to work on it. The reason would not make me worried to cultivate peanuts was that the harvest would be bought by Mr. Steddy since I am a loyal customer." Mr. Fany Ratu also considers that he is not afraid of having farm businesses on peanuts since practically it is common becoming peanut farmer. His harvest might be purchased by Mr. Steddy, a roasted peanut entrepreneu. This relationship has been established through a long process as both of them live in a same village and have known each other since childhood. They have understood each other's personality; therefore, this relationship must exist since they live together in the same village.

In the other hand, Mr. Jolen Rawis always sells his harvest to Mr. Steddy since they are family.

"Mr. Steddy and I are relatives. His wife and I are siblings, so, when I plant and corp peanuts, I will sell to Mr. Steddy. It is common to give different price since I sell to my relative".
What has been said by Mr. Jolen indicates that relatives also put power on the relationship which has been established; although, there is different price. It might be a problem to sell the peanuts to them since they would rather prioritize a relationship than money. The power of social capital joins both parties to support their business as they know that a good cooperation will make them survive.

It also happens to Mr. Steddy.

"My roasted peanut business is in a good condition; although, sometimes I have difficulties in the stock of raw materials. If it is none or deficient, so the big risk is no production. We employ some workers for this business, and I am relieved when I do not need to find raw materials in other places since all farmers are loyal to sell their corps to me.

This statement indicates that relationship built between farmers and roasted peanuts businessmen may decrease their afraidness of the loss of raw materials. They may have communication when in harvest time and must keep their relationship so that they may maintain the relationship.

\subsubsection{Mutual Trust and Cooperation}

Trust is very important in farming activities and roasted peanut processing business and plays a very important role in every business trip. Trust issues sometimes make business collapsed as told by one community in the following.

“ In the very beginning, Mr. Noldy's business ran well with very good products; however, when in harvest time, his corps were attacked by pest. He made a lie on them, and in the result, some entrepreneurs of roasted peanut do not want to purchase his low quality products anymore."

The previous statement implies that farmers' intransparancy to entrepreneurs about their low quality products may lead to a bad relationship and reduce trust. It may result to negative effects which leads to distrust of entrepreneurs to the farmers. Another case was experienced by Mr. David who had been planting peanuts for a long time. He never hesitated to sell his corps to Mr. Steddy because they had known each other for a long time. If the results were low, he would honestly tell him. Although the price was different from the results of good quality, but the fearness of the unsold corps never existed. He explains in the following statement.

In another case experienced by Mr. David who has been planting peanuts for so long is that he never hesitates to sell corps to a loyal customer like Mr. Steddy since they have known each other. If he has low quality products, he will tell him. It is no problem if the price is different since he is not afraid of unsold products.

The previous statement proves that transparancy between agents are required. Mr. Aring never worries on the low price when in big harvest since his products are definitely bought by Mr. Steddy. The worriness of unsaleable products is disputed since the existence of honesty and transparancy.

Therefore, Mr. Steddy as an entrepreneur, never refused the crops that are being offered by the farmers because he knows that the farmer's harvest is good and not 
disappointed. If there is a problem, farmers will usually be honest.

"Mr. David is my loyal customer for 15 years; therefore, we know each other. He knows the ups and downs of my business. He always sell his products to me. He is always honest with the quality of the peanuts.

Concerns with quality beans won't haunt the roasted peanut businessman because he believes his customers will always give their best. Therefore, in buying and selling activities between farmers and entrepreneurs do not use agreements on paper. It is enough to believe they can already sell and buy the products, so they do not use a guarantee letter. In a certain period they will immediately pay off the peanut to the farmers on time as in agreement.

\subsubsection{The Obedience of Norms of Life}

Norms are policies in society. They are written and have been created due to the culture of ancestors from generation to generation. In this industry, existing norms or policies are ingrained in society; although, it is not clearly written. They have formed through some agreements of community as stated by Mr. Aring on how policies can keep them from bad situations in the following statement:

"'In a harvest time, we are actually free to sell our products; however, the norms have rules us to supprot each other and pull together."

This statement explains that an agreement must be obeyed to maintain relationship between two agents. It makes both businesses survive since the obedience results community dynamically run their business without any burden.

Thus, the process of selling and buying transaction between farmers and entrepreneurs results an agreement of size. Mostly, they use bushel for the measurement. A bushel contains 28 liters of raw peanuts; however, lately, the measurement changes into a sack of whitr nylon. A sack consists of five bushels. In a normal condition, a sack is priced IDR 500,000, yet in a low stock condition, it may reach to IDR 600,000. This regulation has been applied in society. Mr. Steddy explains an additional issue which also has been agreed in society in the following statement.

"Mr. David and I have known each other. When he have low-quality products, I might purchase it but in low prices. It is not a big deal for him since the standard of selling product is high."

Mutual understanding to run business may lead two agents support each other. Standard and quality of the products must be noticed in order to satisfy consumers; therefore, it is common to follow the tules without making other disappointed.

\subsubsection{Mutual Virtue}

Mutual virtue has been created and closely related to the local community and more specifically between farmers and entreprenurs. This phenomenon may be seen in the daily life. For example, if there are farmers who do not have seed capital to grow peanuts, the entrepreneurs will lend the seeds to the farmers. This was revealed through an explanation of Mr. Donald Paendong. "During the planting season, I did not have seeds. I initially borrowed some money to buy them, but when I came to Mr. Steddy, he borrowed some seeds to me.
Mr. Steddy's kindness is a plus point which results that Mr. Donald sell his corps to him. The seeds loaned are usually cut immediatly at buying the corps. It confirms that the ability to establish relationship may maintain businesses of both agents. This condition is also expereinced by $\mathrm{Mr}$. Maxi, Mrs. Jelly, and Mr. Frely and other entrepreneurs. They sometimes lend both seeds and money in order to keep them being loyal.

\subsubsection{Impact Values of Life}

The value of life in society is influenced by traditional values inherited from the ancestors of Minahasa people. Life values of people are also influenced by the spiritual teachings taught by the religion adopted by the Kawangkoan community for example, mutual assistance in supporting family income. Mr. Max employed several workers in his roasted peanut business. Seeing his surrounding neighbors woke him up to help them to get money for their family. When they work at Mr. Max's place, they get money to finance their families. Mr. Max never pressed his employees yet gave them understanding; therefore, the relationship with employees is mutual and fair.

\subsection{The Forms of Social Capital Design}

The identification of a formation of positive social capital indicates that small industry business experiences growth. This also requires the support of the government as a regulator and community leaders to jointly build togetherness by helping "Collections" consisting of peanut farmers and roasted peanut entrepreneurs. This collection is made should have a vision and mission to develop this business so that it has an economic impact on society. The formation of a new design for business development can be formulated in several ways such as the following explanations.

\subsubsection{Excavating and Exploring the Resources of} Members of the "Association"

The resources owned by members of the group should continue to be explored and explored in real terms. This association is able to multiply every ability possessed by members in terms of utilizing human resources that have special skills in managing business ventures. Usually members of the association will also be invited by junior farmers who have not experienced managing their farming, they can share knowledge. It certainly does not require big money. Similarly, the senior roasted peanut entrepreneurs may share knowledge to their junior about initiating business. This activity may result a positive effect for the future development.

Thus, natural resources must always be developed. In fact, the taste of roasted peanuts from Kawangkoan is different from other regions. This advantage should be used as a power to continue running the business. As seen in sangari peanuts produced by a small enterprise in Kawangkoan, they has different shape and taste since they are tasteful and savory. This powerful tase makes consumers want to repurchase. Roasted peanuts from Kangkoan are 
processed without chemicals yet only use natural ingredients such as using firewood and fine sand for roasting process. This simple process requires special skill to make them easily popular. Therefore, each member should take this advantage for theur small business in order to make them popular and beneficial.

\subsubsection{Protecting and Guarding the Members from Their} Business Threat

The business of roasted peanuts, of course, can be threatened with bankruptcy every time. As seen from the community who initiates their business with reckless capital, a small capital to run this business. In a few moments, it means closed when it does not appear. It is a quite complicated problem since it indicates failure. Therefore, the function of the association should be able to facilitate its members by cooperating with financial institution in order to join a funding network such as with a bank or a saving and loan cooperative, and they should help members in terms of capital ease. All members of the group are obliged to protect and secure each other in terms of facilitating the loan of capital to the bank or to a saving and loan cooperative. It actually may help members to carry out their business so that they can expand their business without feeling alone in lending money capital. Thus, facing competitors of roasted peanuts of various brands, group members should be able to minimize any threat by improving the quality of roasted beans since collective members should produce good and quality products. If roasted beans do not have quality inthe market, consumers definitely will consume modern processed peanuts which have great taste and packaging. In facts, sometimes roasted peanuts are produced in low quality such as in different taste (some are sweet, and the rest are not) and sometimes has no meat. It is very disappointed; therefore, every single problem should be learnt. It leads to have commitment to treat the customers. An association as a protector and security should train and provide awareness to members to run roasted peanuts by producing high quality products, so the owner of modern business is no longer as a significant competitor. Kawangkoan roasted peanuts themselves have a special place in consumers' heart; therefore, the members should determine to run and give the best products in order to fight the competitors.

\subsubsection{Utilizing Every Business Opportunity for Business} Development

Business opportunities may easy come and easy go. Members of the association should earlierly be able to identify every business opportunity that can be achieved, for example, in terms of getting a chance to get funding from the government or a capital loan. Every opportunity should be used properly by group members. In terms of market expansion, members of the association should have a lot of information about the market, consumers, and producers since these opportunities are often ignored. Association members can develop their marketing capabilities by expanding their business, so the roasted peanuts are not only stored and sale in certain areas but also in online. They may ask IT staff to develop marketing online, so the products can be easily bought by people all over the world. It is of course requires special training in order to expand in a better version. They also need to absorb knowledge to make innovation from internet, for example in packaging. All this time, sellers only make a packaging of roasted peanuts using common plastic which do not give exclusive impression.

Therefore, it should be product design and development by utilizing every opportunity in order to make the products unique and available anywhere and anytime. Sometimes, the products are difficult to find since the raw materials are seasonal; therefore, the clear regulations should be obtained. The uniqueness of this product should be figured from the packaging, so the innovations should be developed to conquer the market.

\subsubsection{Identifying and Anticipating every Threat of a} Small Business

The threats of small business businesses can be seen internally and externally. Internal ones can be seen in a relationship between fragile group members; therefore, they are required power. Living and running business alone is not easy, so humans as social beings need to have communities / associations that make them stronger. As experienced by farmers and entrepreneurs, their efforts will not go well if they do not guard to strengthen relationship between fellow members because there are so many problems in small industrial businesses. The powerof fellow members will provide new energy which make them survive. Internal threats within groups can be seen in terms of business competition, where more experienced entrepreneurs will dominate the market because of large capital, so small or junior entrepreneurs will find it difficult to develop their businesses which may not be known by the public. Therefore, competition in a group should be arranged in such a way as to minimizing without harming both parties. This is also undeniable with members of the association who do not understand the norms by selling low-quality products which may affect the damage of institution.

Therefore, threats can be minimized by providing awarness of right norms and life values. Norms are policies existing in society both in oral or written. As in an association, every member should obey the written rules, for example having transaction of selling and buying among members and keeping their promise to pay the loans as stated in an agreement. No one can sell low-quality product since every member must be honest when they have lowquality product. Another regulation which shoulde be notice by members are nurturing honesty when they are having transaction although they have no memorandum; therefore, they need to head straight for the agreement.

The other internal threats are in the aspect of trust among association members. Trust is so crusial that relates to many aspects. People who cannot be trusted are not accepeted by society. Therefore, trust is required to succed members' association for their business development. A small business of roasted peanuts should build trust among its members, for example when buyin peanuts from farmers to roasted peanut entrepreneurs, it requires their quality. In a community, it does not need tight monitoring in selling and buying products, yet it is required to give trust to the business activity without having so much energy. 
Other internal factors are found in terms of minimizing compeitors and maximizing the virtue of members of the association. In terms of association membership of tore bean business, individuals' bad habits should be minimized and eliminated since it may affect the relationship among members. Some members sometimes still bring their bad behaviors to interact with other members, for example: there are two close friends who do not want to be separated and mingle with the others and who are not willing to share knowledge about their business. It is not possible to have individuals who like to make some provocations. This kind of behavior should be eliminated since it will bother the member should be maximized or enhanced, for example in terms of giving assistance to some fellow members in order to share knowledge. It is such a good behavior that makes new members learn how to run business properly. The presence of seniors who are willing to share knowledge will have a positive impact on the development of their business, and the capital of business often considers as an obstacle in business development. Entrepreneurs who have more capital should be assist the other members by providing money in order to make poor members survive. Another internal factor is maintaining and preserving the value of life as a role model for everyone. It is not easily maintained which results not all people succeed to live properly. For example, somebody is once willing to help other entrepreneurs who face some difficulties in running business, but when they are already successful, they gradually change themselves. Therefore, it sometimes dos not reflect the good value of live since they only follow their ego and do not care with other people. As we know that in daily life, people need and relate each others, but sometimes some of them like to say bad things about others' products and businesses. They are also not willing to share knowledge since they considers their friends as competitors; therefore, all information related to marketing are closed. These behaviors should be eliminated and replaced by preserving values of life as taught by a national hero from North Sulawesi, GSSJ Ratulangi through his slogan "sitou timou tumo tuo" which means turning on life. It is strongly belived in order to maintain social capital to form values in society.

External facors are coming from competitors of new innovations of local roasted peanuts such as new in taste, packaging, and marketing. They have been backed up by big companies. Considering this condition, association should do some innovations and strategies in order to preserve these roasted peanuts. They need to aware of some threats and should realize an innovation of roasted peanuts from Kawangkoan.

\section{CONCLUSION}

Most problems faced by small industrial enterprises do no stop to run the business. The existence of negative social capital does not fall off the business. The power of positive social capital is present as an illuminator who revives the life of this small industrial business. Although having to face various problems both inside and outside. Positive social capital is found through a process in terms of: (1) The Power of Colleague Network, (2) Mutual Trust and Cooperation, (3) Obedience to Life Norms, (4) Mutual association. In the other hand, some plus points of each

Vurtue and, (5) Impact Values of Life. The process of a long journey of social capital has made it even more complete with the formation of a design of social capital through a community / group formed specifically consisting of peanut farmers and roasted peanur entrepreneurs. The set that is intended for: (1) Excavating and Exploring the Resources of Members of the "Association". (2) Protecting and Guarding the Members from Business Threats. (3) Utilizing Every Business Opportunity for Business Development in a Better Version. (4) Identifying and Anticipating every Threat of a Small Business. The process of social capital has become a force contained in the design of social capital which has an overall impact on the strengthening and development of small industrial economies. It also requires support and the role of the government as a regulator for the sustainability of small industrial businesses to continue to take part and be able to prosper the community's economy. This has become the strength of small industry businesses to continue to employ their capabilities in the business world both nationally and internationally.

\section{ACKNOWLEDGEMENTS:}

This research is supported by Jesus Lord, the Direktorat Riset dan Pengabdian Masyarakat RISTEKDIKTI Indonesia and AIMC UTM 2019.

\section{REFERENCES}

1. J. Hasbullah, "Social Capital Menuju Keunggulan Budaya Manusia Indonesia. MR-United Press Jakarta, 2006.

2. . R.W. Kimbal, " Modal Sosial Dan Ekonomi Industri Kecil” Sebuah Studi Kualitatif, 2015, pp. 1-242 https://books.google.co.id deepublish publish.

3. A.E. Yustika, "Ekonomi Kelembagaan Definisi, Teori dan Strategi, Bayumedia Publishing Anggota IKAPI Malang, 2008.

4. N. Faturahman, "Proses Sosial dan Interaksi Sosial. http://www.academia.edu/.

5. J. Hasbullah, "Social Capital Menuju Keunggulan Budaya Manusia Indonesia. MR-United Press Jakarta, 2006.

6. Lin, Nan. "Social Capital: A Theory of Social Structure and Action. Cambridge University Press. Cambridge. Uk, 2001.

7. A. Sudrajat, "http://bentuk-bentuk dan aturan dalam interaksi sosial.htm/20/12/2012.

8. R.W. Kimbal dkk, "Social Capital Contribution to Economic Actors in Mix barter Transaction In Pasar Blante Kawangkoan.https://doi.org/10.2991/icss-182018.176.

9. R.W. Kimbal, “ The design of ideal social capital for the development of traditional market mix in the barter transaction in pasar blante Kawangkoan" ijaber, Vol, 13 No.7pg.5703-

5720,2015 ,serialsjournals.com/serialsjournalmanager/pdf /1457769317.pdf.

10. R.W. Kimbal, ”The Exitence Of Social Capital and Their Contribution To The Empowerment of Roasted Peanut as a small Industry in Indonesia. IJET Journal vol 7 No 3.25.2018 pp 321-328 special issue 
25.www.sciencepubco.com/index.php/ijet.

11. Sugiyono, "Memahami Penelitian Kualitatif Alfabeta. Anggota IKAPI Bandung pp 113-114, 2005.

12. H.Wijaya, S. Tinggi, F.Jaffray, " Analisis Data Kualitatif Model Spradley. 2018;(March).

13. M. Idrus, Metode Penelitian Ilmu-Ilmu Sosial (Pendekatan Kualitatif dan Kuntitatif).UII Press Yogyakarta, 2007.

\section{AUTHORS PROFILE}

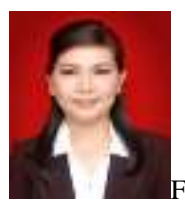

First Author: R.W Kimbal completed her bachelor degree majoring on Socio-economic department of Faculty of Agriculture, Sam Ratulangi University. She is honored with Cum Laude Predicate from Brawijaya University as she gained her Master and Doctorate Degree on Economics and Development studies of Faculty of Economics and Bussiness. Besides as a fulltime lecturer in Universitas Negeri Manado, she is currently a head of laboratory of Economics study program of Faculty of Economics of the university. She was awarded the best paper in two different conferences namely International Conference on Political Economy of Trade Liberalization in Developing South East Asia held by Brawijaya University on 24-25 November 2011 in Malang, and National Seminar of ISEI (Indonesian Economist Association) on 20-22 July in Bandung. She was also one of the ten best authors selected for JIEB Journal edition of Universitas Gadjah Mada in 2011. In addition to teaching in her current institution, She is also teaching in faculty of Economics of Indonesia Open University. Her book on "Social Capital: A Qualitative Study on Small Industry and Traditional Market (2014)" has been widely read. Her publications are traced in nine articles published in indexed journals, eight proceedings, four reference book and one teaching material book. She is has been active as editor and honorary editor in several national journals. As a researcher, she is currently having a research project from Directorate of Research and Community Outreach, Ministry of Research, Technology and Higher Education, Indonesia. She once involved in several institutions such as Bappeda Jawa Timur and Riau, PNBP Research Unima, and other community outreach programs. In relation to the capacity, she has been invited to be speakers in both local and national seminar and workshop. Her profession organization experience is marked as her inclusion in regional board of North Sulawesi of ISEI (Indonesia Economist Association) since 2018. 